\title{
A psychometric evaluation of the Caregiver Contribution to Self-Care of Heart Failure Index in a Thai population
}

\author{
Nittaya Srisuk ${ }^{1}$, Nutchanath Wichit ${ }^{1}$, David R. Thompson ${ }^{2^{*}}$ (1) and Chantal F. Ski ${ }^{3}$
}

\begin{abstract}
Background: Caregivers are major contributor to the self-care of patients with heart failure. The Caregiver Contribution to Self-Care of Heart Failure Index (CC-SCHFI) measures these contributions across three scales: self-care maintenance (symptom monitoring and treatment adherence); self-care management (dealing with symptoms); and confidence in contributing to the self-care (self-efficacy in managing self-care) of patients with heart failure. Informal caregivers play a vital role in supporting family members with heart failure in Thailand, yet no validated tool exists to measure their contribution. We examined the psychometric properties of the CC-SCHFI in a Thai population.

Methods: The CC-SCHFI was translated into Thai using a standard forward and backward translation procedure. A cross-sectional design was used to examine the psychometric properties of the Thai version of the CC-SCHFI in 100 family caregivers of heart failure patients in Southern Thailand. Confirmatory factor analysis was used to assess construct validity, and factor score determinacy coefficients were computed to evaluate internal consistency reliability.

Results: The Thai version of the CC-SCHFI demonstrated acceptable internal consistency (composite reliability of each scale ranged from 0.76 to 0.99). Reliability estimates were adequate for each scale (McDonald's omega ranged from 0.75 to 0.96 ). Confirmatory factor analysis supported the original factor structure of the instrument, with good fit indices for all three scales (comparative fit index $=0.98-1.00$; root-mean-square error of approximation $=0.00-0.07$ ).

Conclusions: The Thai version of the CC-SCHFI appears to be a valid and reliable instrument for measuring caregiver contributions to self-care maintenance and self-care management as well as contributing to caregiver confidence in the self-care of Thai heart failure patients.
\end{abstract}

Keywords: Psychometric evaluation, Caregiver Contribution to Self-Care to Heart Failure Index, Thai, Translation, Reliability, Validity

\section{Background}

Heart failure is a complex life-limiting condition associated with a high rate of mortality, high symptom burden and poor quality of life. Globally, over 26 million people have heart failure [1]. The condition is worse in Thailand, where patients hospitalised for heart failure are younger

*Correspondence: David.Thompson@qub.ac.uk

${ }^{2}$ School of Nursing and Midwifery, Medical Biology Centre, Queen's University Belfast, 97 Lisburn Road, Belfast BT9 7BL, UK

Full list of author information is available at the end of the article and sicker, than Europe and the US [2]. Thailand, with a growing population of 70 million people, is categorized as an upper middle-income country [3]. As with other Southeast Asia countries, it has a high prevalence of cardiovascular disease risk factors, notably hypertension and raised blood glucose/diabetes, and thus of symptomatic heart failure [3]. Though data are sparse, in Thailand about $6 \%$ of people admitted with heart failure die in hospital [4]. One-year, five-year and ten-year mortality rates in Thai patients admitted for acute decompensated heart failure were $28 \%, 58 \%$ and $73 \%$, respectively [5]. original author(s) and the source, provide a link to the Creative Commons licence, and indicate if changes were made. The images or other third party material in this article are included in the article's Creative Commons licence, unless indicated otherwise in a credit line to the material. If material is not included in the article's Creative Commons licence and your intended use is not permitted by statutory regulation or exceeds the permitted use, you will need to obtain permission directly from the copyright holder. To view a copy of this licence, visit http://creativecommons.org/licenses/by/4.0/. The Creative Commons Public Domain Dedication waiver (http://creativeco mmons.org/publicdomain/zero/1.0/) applies to the data made available in this article, unless otherwise stated in a credit line to the data. 
As the burden of heart failure increases in Thailand and other emerging economies, developing culturally appropriate, affordable and acceptable models is necessary [6]. This includes acknowledging the vital role family members play as informal caregivers of patients with heart failure in Thailand [7], a rapidly rising elderly population, and the burden imposed on caregivers [8,9]. Such models are likely to be characterized by a systematic, coordinated and integrated approach to individual (patient/caregiver) assessment and intervention, ideally in the home or local community centre, but with access to specialist expertise at the local hospital or clinic. This will, of course, be determined by social, cultural and organizational structures and systems, such as beliefs and health insurance coverage, but aim to optimize health care and improve health outcomes and experience, confidence and satisfaction with care. Quality criteria should include equity and equality of opportunity to adherence to evidence-based assessments and treatments, counselling and health education, continuity and timely care, all underpinned by patient choice and preferences. Equally important is health care organized and delivered by competent, credentialed professionals with access to evidence-based guidelines and treatments $[6,10]$.

In Thailand, on initial admission and after diagnosis, patients with heart failure usually present with dyspnea, edema and weakness with common precipitating factors being noncompliance with diet and medication [11]; all preventable through appropriate self-care. Effective heart failure self-management strategies include adherence to complex medication regimens, exercise, daily weight and symptom monitoring and, where necessary, acting on these, as well as recommending other lifestyle behaviours [12]. Yet effective self-care practices, which can reduce re-hospitalization and mortality and enhance quality of life [13], is suboptimal among Thai patients with heart failure [14] with most requiring support from their family caregiver [15]. Further, although caregivers make an important contribution to the self-care of patients with heart failure, to date no instrument has been available to measure 'caregiver contribution' among patients with heart failure in Thailand.

The pivotal contribution of the caregiver to heart failure self-care in Western countries is well recognized, yielding improvements in health-related quality of life, re-hospitalization rates, adherence to treatment and engagement in self-care. Internationally, there is evidence that caregivers play a crucial role in supporting heart failure patients. For example, a recent systematic review and meta-analysis found that higher caregiver strain was associated with worse patient symptoms and quality of life [16]. The American Heart Association has indicated that it is critically important to understand the needs of caregivers to support the increasingly complex medical care they provide to patients living with heart failure [17]. In Thailand, where family members play a fundamental role in caring for their elders $[8,9]$, evidence pertaining to heart failure caregivers is limited, though it suggests that they are constrained in their caregiving role by factors such as inadequate knowledge and support, which can be improved by a simple family based-intervention [15]. The contribution of caregivers towards patients' heart failure self-care is unclear due to the absence of a validated instrument for use in a Thai population.

In Western countries a number of instruments have been developed to measure caregiver contribution to heart failure self-care, including the Caregiver Contribution to Heart Failure Self-Care (CACHS) instrument [18], the Heart Failure Caregiver Questionnaire (HF-CQ) [19], the Caregiver Burden Questionnaire Heart Failure (CBQHF) [20] and the Caregiver Contribution to SelfCare to Heart Failure Index (CC-SCHFI) [21], recently revised [22], which is derived from the Self-Care of Heart Failure Index (SCHFI) [23] and has adequate reliability (Cronbach $\alpha>0.80$ ).

Of these instruments, only the SCHFI [24] is available in a Thai version. As the CC-SCHFI was derived from this, we aimed to translate and evaluate the psychometric properties of the CC-SCHFI in a sample of Thai speaking caregivers of patients with heart failure admitted to hospital in southern Thailand. Moreover, though the CC-SCHFI has been translated and used in Asian countries such as China, Korea, Japan, Vietnam and Indonesia which have similar, but not identical, social and cultural characteristics as Thailand, the Thai version of the CCSCHFI may help provide nuanced insights into the role of heart failure caregivers in this population.

\section{Methods \\ Study design}

We conducted a cross-sectional study at two public hospital heart failure clinics in southern Thailand. A convenience sample of adult caregivers of patients with heart failure at each site was enrolled. All had been designated by patients as their primary caregivers and were older than 18 years of age, and able to read and write in Thai. All questionnaires were paper-based and self-administered. Data were collected between March to November 2020.

This study was approved by the Institutional Review Board of Suratthani Rajabhat University (SRU 2019_038). All research participants provided written informed consent and were informed of their right to withdraw anytime during the course of the study. The study conforms with the principles outlined in the Declaration of Helsinki. 


\section{Instrument}

The CC-SCHFI version 1 comprises 22 items divided across three scales: caregiver contribution to self-care maintenance; caregiver contribution to self-care management; and caregiver confidence in contributing to self-care [21]. The caregiver contribution to self-care maintenance scale comprises 10 items that measure caregiver contributions to symptom monitoring and treatment adherence. The caregiver contribution to self-care management scale comprises 6 items that measure caregiver ability to recognize symptoms of heart failure decompensation when they occur, to implement treatment in response to these symptoms, and to evaluate the treatments used. The caregiver confidence in contributing to self-care scale comprises 6 items that measure caregiver confidence in their skills in helping patients to engage in each phase of the self-care process. Each of the three scales uses a 4-point Likert response scale (for selfcare maintenance 'never or rarely, sometimes, frequently, always or daily'; for self-care management 'not likely, somewhat likely, likely, very likely'; and for confidence in contributing to self-care 'not sure, somewhat sure, sure, very sure') with a standardized score from 0 to 100 , higher scores indicating higher contribution to self-care [21].

\section{Instrument translation}

The English version of the CC-SCHFI was forward and backward translated using the following techniques. Permission to use the CC-SCHFI was sought and obtained from the creator [21]. Two bilingual translators independently translated the instrument from English into the Thai language. This was followed by another review and verification by a bilingual (English and Thai) researcher and two translators who assessed the concepts and the appropriate use of language. At a later stage, two independent bilingual translators translated the Thai version of the CC-SCHFI back to English [25]. The translations were compared with the original to identify and amend any incorrect use of language and potential misinterpretations by the creators. The Thai version of the $\mathrm{CC}$ SCHFI is provided in the "Appendix".

\section{Sample size}

Like a similar recent study evaluating the psychometric properties of the CC-SCHFI in a South American population [26], we determined a sample of seven participants per item was needed to allow adequate inference in confirmatory factor analysis [27]. As the CC-SCHFI has three separate scales, each measuring a different construct, with self-care maintenance being the longest scale, with 10 items, a sample of 70 participants would suffice to address dimensionality and internal consistency. However, as with the recent evaluation [26] that enrolled 99 participants to support a more stable analysis [28], we aimed to recruit a sample of 100 participants.

\section{Data analysis}

Descriptive and inferential statistics were used to analyse the data. The Kaiser-Meyer-Olkin measure of sampling adequacy and Bartlett test of sphericity were used to assess data factorability. Confirmatory factor analysis (CFA) was used to test the construct validity of the Thai version of the CC-SCHFI and factor loading of the three scales. Maximum likelihood estimation was used to determine values for the parameters of a model [29]. Internal consistency reliability was tested by estimating item-to-total correlations using Spearman correlation coefficients. The item-to-scale correlation should exceed 0.4 [30]. Composite reliability (CR) of each latent variable and the average variance extracted (AVE) were calculated. McDonald's omega coefficient was used to estimate the reliability [31, 32].

Similar to a previous study [26], we evaluated the following fit indices and criteria [33-39]: the comparative fit index (CFI), goodness of fit index (GFI), adjusted goodness of fit index (AGFI), incremental fit index (IFI); normed fit index (NFI), root mean square error of approximation (RMSEA), root mean square residual (RMSR). Regarding the CFI, values in the range of 0.90 to 0.95 indicate acceptable fit and values of 0.95 or higher indicate good fit [37]. The RMSEA was used to evaluate lack of model fit, where values of 0.05 or lower indicate a well-fitting model, values between 0.05 and 0.08 indicate moderate fit, and values of 0.10 or higher indicate poor fit. The RMSR was used to evaluate the fit in the sample, where values of 0.08 or lower indicate good fit.

\section{Results}

\section{Sample characteristics}

The sample comprised 100 caregivers of patients with heart failure (Table 1). Most caregivers were women (69\%), with a mean age of 39 years; $51 \%$ were daughter or son.

\section{Item descriptive analysis}

Table 2 shows descriptive statistics for the individual items of the CC-SCHFI. The highest-scoring items in the caregiver contribution maintenance scale were 'keep doctor or nurse appointments' and 'eat a low salt'. Items related to 'exercise for $30 \mathrm{~min}$ ' and 'use a system (pill box, reminders) to help him/her remember medicines' scored lowest. On the caregiver contribution to self-care management scale, the item that scored highest was 'reduce the salt in diet' whereas 'take an extra water pill' scored 
Table 1 Sociodemographic characteristics of informal caregivers

\begin{tabular}{ll}
\hline Sociodemographic characteristics $(\mathbf{n}=\mathbf{1 0 0})$ & $\mathbf{n}$ (\%) \\
\hline Gender & 69 \\
Female & $39.2(8.5)$ \\
Age (mean, SD) & \\
Educational level & 22 \\
No formal education & 16 \\
Primary school & 28 \\
Secondary school/college & 34 \\
Bachelor or higher & \\
Occupation & 24 \\
Employee & 44 \\
Business owner/ trader & 15 \\
Farmer & 11 \\
Public employee & 6 \\
Unemployed/student & \\
Relationship with patient & 29 \\
Spouse & 51 \\
Daughter/son & 8 \\
Sister/brother & 12 \\
Other &
\end{tabular}

lowest. On the caregiver confidence in contributing to self-care scale, the highest-scoring item was 'follow the treatment advice.' The lowest-scoring item was 'prevent heart failure symptoms'.

The Bartlett test of sphericity was significant $(\mathrm{p}<0.0001)$, and the Kaiser-Meyer-Olkin index of sampling adequacy was 0.670 . Based on these results, the data were suitable for factor analysis.

\section{Confirmatory factor analysis}

Findings of the CFA for each of the three CC-SCHFI scales and the index are presented below and in Figs. 1, 2,3 and 4 .

\section{Caregiver Contribution to Self-care Maintenance Scale}

The self-care maintenance variables (10 latent variables) show acceptable threshold levels, Chi-square $=18.41$, $\mathrm{df}=15.0, p=0.24, \mathrm{CMIN} / \mathrm{df}=1.23<2.0$, consistent with the concept [33-39], and a reasonable fit of the index of model to the data on the basis of a number of fit statistics, including $\mathrm{CFI}=0.99, \mathrm{GFI}=0.97, \mathrm{AGFI}=0.87$, RMSEA $=0.05$, RMSR $=0.02, \mathrm{NFI}=0.90$ and $\mathrm{IFI}=0.99$. Squared Multiple Correlations $\left(\mathrm{R}^{2}\right)$ ranged from $18 \%$ - 99\%, and the standardized factor loadings ranged from $0.42-0.99$. The CFA of the self-care maintenance model strongly suggests that each set of items represents a single underlying construct and provides evidence for discriminate validity or acceptable fit (Fig. 1).

\section{Caregiver Contribution to Self-care Management Scale}

The self-care management variables (6 latent variables) show acceptable threshold levels, Chi-square $=2.41$, $\mathrm{df}=3.0, p=0.49, \mathrm{CMIN} / \mathrm{df}=0.80<2.0$, consistent with the concept [33-39], and a reasonable fit of the index of model to the data on the basis of a number of fit statistics including $\mathrm{CFI}=1.00, \mathrm{GFI}=0.99, \mathrm{AGFI}=0.95$, RMSEA $=0.00, \quad \mathrm{RMSR}=0.02, \quad \mathrm{NFI}=0.99, \quad$ and IFI $=1.00 . R^{2}$ ranged from $26 \%-58 \%$, and the standardized factor loading ranged from $0.49-0.76$. The CFA of the self-care management model strongly suggests that each set of items represents a single underlying construct and provides evidence for discriminate validity or acceptable fit (Fig. 2).

\section{Caregiver Confidence in Contributing to Self-care Scale}

The self-care confidence variables (6 latent variables) show acceptable threshold levels, Chi-square $=13.580$, $\mathrm{df}=9.0, \quad p=0.138, \quad \mathrm{CMIN} / \mathrm{df}=1.509<2.0, \quad$ consist ent with the concept [33-39], and a reasonable fit of the index of model to the data on the basis of a number of fit statistics including $\mathrm{CFI}=0.98$, GFI $=0.96$, AGFI $=0.90$, RMSEA $=0.05$, RMR $=0.02$, NFI 0.94, and $\mathrm{IFI}=0.98 . \mathrm{R}^{2}$ ranged from $36 \%-59 \%$, and the standardized factor loading ranged from $0.60-0.77$. The CFA of the self-care confidence model strongly suggests that each set of items represents a single underlying construct and provides evidence for discriminate validity or acceptable fit (Fig. 3).

\section{Caregiver Contribution to Self-Care of Heart Failure Index}

The model for the Thai version of the CC-SCHFI (Fig. 4) identified the three latent variables of self-care maintenance, self-care management and self-care confidence. $\mathrm{R}^{2}$ across the three scales ranged from 17 to $84 \%$, and the standardized factor loading ranged from 0.41 to 0.92 more than 0.40 . The average variance extracted, which measures the variance captured by the indicators relative to measurement error, ranged from 0.52 to 0.59 and composite reliability ranged from 0.76 to 0.99 [40, 41]. McDonald's omega ranged from 0.75 to 0.96 $[31,32]$ (Table 3). Item-total correlations ranged from 0.42 to 0.67 . These acceptable values strongly suggest that each set of items represents a single underlying construct and provides evidence for discriminate validity. For each of the three scales an acceptable model fit was demonstrated based on a number of fit statistics (Table 4). 
Table 2 Descriptive statistics for individual items of the Thai version of the CC-SCHFI

\begin{tabular}{|c|c|c|c|c|c|c|}
\hline Items & Min & Max & Mean & SD & Skewness & Kurtosis \\
\hline \multicolumn{7}{|l|}{$\begin{array}{l}\text { Caregiver contribution to self-care maintenance } \\
\text { How often do you recommend that the person you care for do the following things? }\end{array}$} \\
\hline 1. Weigh daily & 1 & 4 & 2.47 & 0.72 & 0.52 & -0.12 \\
\hline 2. Check ankles for swelling & 1 & 4 & 2.70 & 0.82 & 0.05 & -0.68 \\
\hline 3. Try to avoid getting sick (e.g. flu shot, avoid ill people) & 1 & 4 & 2.79 & 0.81 & -0.18 & -0.47 \\
\hline 4. Do some physical activity & 1 & 4 & 2.48 & 0.73 & .038 & -0.19 \\
\hline 5. Keep doctor or nurse appointments & 3 & 4 & 3.80 & 0.40 & -1.52 & 0.32 \\
\hline 6. Eat a low-salt diet & 1 & 4 & 3.22 & 0.75 & -0.53 & -0.51 \\
\hline 7. Exercise for $30 \mathrm{~min}$ & 1 & 4 & 2.13 & 0.92 & 0.53 & -0.43 \\
\hline 8. Remember to take medicines & 1 & 4 & 3.04 & 1.13 & -0.68 & -1.04 \\
\hline 9. Ask for low-salt items when eating out or visiting others & 1 & 4 & 2.58 & 0.78 & 0.24 & -0.48 \\
\hline 10. Use a system (pill box, reminder) to help him/her remember to take medicines? & 1 & 4 & 2.23 & 0.85 & 0.33 & -0.40 \\
\hline \multicolumn{7}{|l|}{ Caregiver contribution to self-care management } \\
\hline \multicolumn{7}{|l|}{$\begin{array}{l}\text { If the person you care for has trouble breathing or ankle swelling, how likely are you } \\
\text { to recommend (or do) one of the following remedies? }\end{array}$} \\
\hline 12. Reduce salt in the diet & 1 & 4 & 3.12 & 0.81 & -0.58 & -0.30 \\
\hline 13. Reduce fluid intake & 1 & 4 & 2.85 & 0.77 & -0.14 & -0.49 \\
\hline 14. Take an extra water pill & 1 & 5 & 1.54 & 0.94 & 0.22 & 0.78 \\
\hline 15. Call your doctor or nurse for guidance & 1 & 4 & 2.13 & 1.07 & 0.49 & -1.02 \\
\hline $\begin{array}{l}\text { 16. Think of a remedy you tried the last time the patient you care for care for had } \\
\text { trouble breathing or ankle swelling. How sure were you that the remedy helped or } \\
\text { did not help him or her? }\end{array}$ & 0 & 4 & 2.34 & 0.89 & -0.12 & -0.48 \\
\hline \multicolumn{7}{|l|}{$\begin{array}{l}\text { Caregiver confidence in contributing to self-care } \\
\text { In reference to the person you care for, how confident are you that you can: }\end{array}$} \\
\hline 17. Prevent heart failure symptoms? & 1 & 4 & 2.24 & 0.59 & 0.20 & 0.14 \\
\hline 18. Follow the treatment advice? & 2 & 4 & 2.80 & 0.62 & 0.16 & -0.50 \\
\hline 19. Evaluate the importance of heart failure symptoms? & 1 & 4 & 2.60 & 0.59 & -0.25 & -0.26 \\
\hline 20. Recognize health changes in the person you care for? & 1 & 4 & 2.48 & 0.61 & 0.08 & -0.30 \\
\hline 21. Do something that relieves heart failure symptoms? & 1 & 4 & 2.54 & 0.61 & 0.12 & -0.34 \\
\hline 22. Evaluate how well a remedy works? & 1 & 4 & 2.54 & 0.64 & -0.15 & -0.16 \\
\hline
\end{tabular}

For the model of the CC-SCHFI, the scale with the most influence was self-care maintenance (factor loading $=0.74 ; R^{2}=55 \%$ ), followed by self-care management (factor loading $=0.68 ; R^{2}=47 \%$ ) and lastly self-care confidence (factor loading $=0.30 ; R^{2}=9 \%$ ) (Fig. 4).

\section{Discussion}

In this study, we tested the psychometric properties of the Thai version of the CC-SCHFI. To our knowledge, this is the first study to do so. Overall, our results show that the CC-SCHFI is a valid and reliable instrument to measure caregiver contributions to self-care of Thai heart failure patients.

The dimensionality of the CC-SCHFI was determined by performing a CFA of each of the three scales of the index: caregiver contribution to self-care maintenance (symptom monitoring and treatment adherence); caregiver contribution to self-care management (dealing with symptoms); and caregiver confidence in contributing to self-care (self-efficacy in managing self-care). Factor analysis was also performed on the entire CC-SCHFI and demonstrated an overall acceptable model fit to the data. The goodness-of-fit indices supported the hypothesized models from the original CC-SCHFI [21, 26].

As demonstrated in the original study [21], we found the Thai version of the CC-SCHFI had a complex structure that encompassed several distinct aspects related to self-care. The caregiver contribution to self-care management and the caregiver confidence in contributing to self-care scales demonstrated high factor loadings within each scale, attesting to a substantial proportion of common variance among the items. Only two items had low factor loadings on the caregiver contribution to self-management scale, 'Try to avoid getting sick', and 'Use a system (pill box, reminder) to help him/her remember to take medicines', which may be explained in part by social and 


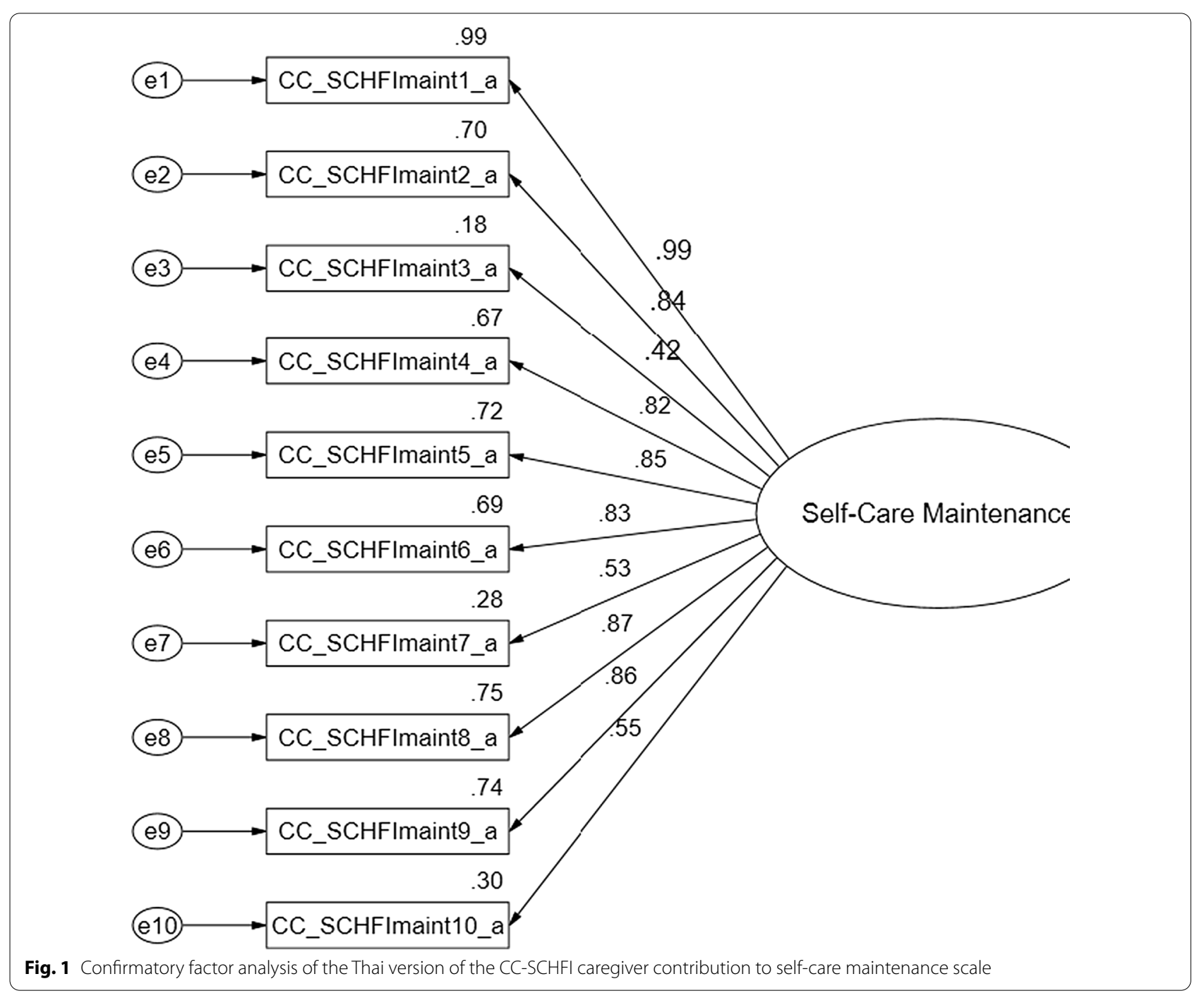

cultural factors, such as the use of pill boxes in rural Thailand being uncommon. Of the three scales, the caregiver confidence in contributing to self-care one was the only scale to have a low factor loading for the overall index, which may again be explained by family, social and cultural structures and mores typical of rural Thailand, such as an essentially patriarchal family structure, with households generally deferring to the eldest members. This may also be compounded by issues such as the likelihood of low literacy levels, lack of health insurance and limited access to health care in Thailand $[6,8]$, particularly in rural and remote regions. Thus, for example, it may be incongruent for a child or a female caregiver to gain confidence in contributing to the self-care of a parent or male, often both.

Our findings are in general agreement with those of the original studies which were conducted with Italian [21] and Brazilian [26] samples. The finding that the selfcare maintenance scale was the most influential is perhaps explained by caregivers, with limited access to heart failure services, playing a major role in symptom monitoring and treatment adherence by, for example, encouraging patients to take exercise, reminding them to attend clinic appointments and ensuring they weigh themselves and follow a recommended diet.

The CC-SCHFI serves as a practical tool for measuring caregiver contributions to heart failure self-care: it can aid caregivers in identifying gaps in heart failure selfcare and in indicating measures to address them. The CC-SCHFI can also assist healthcare providers in guiding and supporting the skills development of caregivers. As self-care is a continuing process, the instrument can be used to monitor individual progress and benchmark this with that of others. It can also act as a motivating force to accomplish self-care.

A strength of our study is the translation and validation of an instrument, hitherto unavailable, to aid informal caregivers in the self-care of Thai people with heart failure. Specifically, the CC-SCHFI provides a comprehensive evaluation 


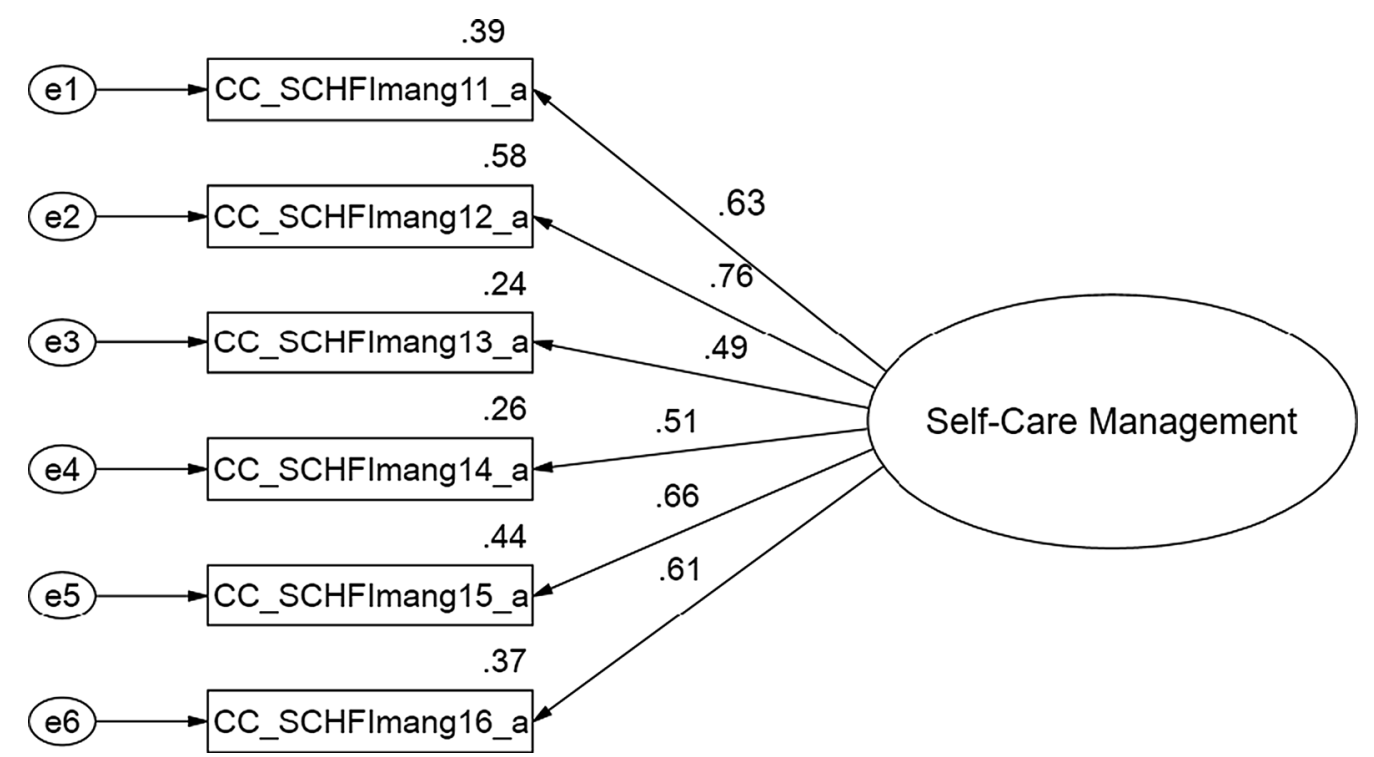

Fig. 2 Confirmatory factor analysis of the Thai version of the CC-SCHFI caregiver contribution to self-care management scale

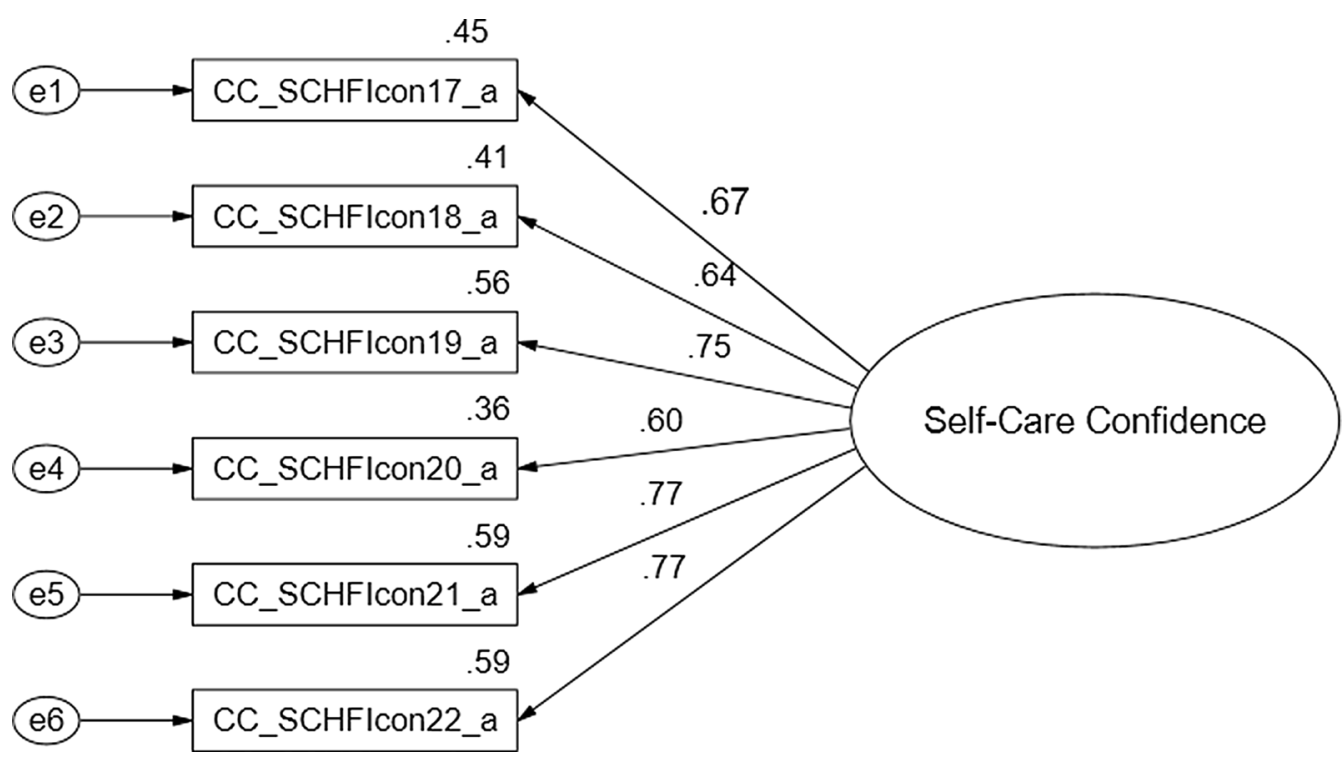

Fig. 3 Confirmatory factor analysis of the Thai version of the CC-SCHFI caregiver confidence in contributing to self-care scale

of caregiver contributions to self-care maintenance, management and confidence, and aids caregivers in identifying potential gaps in these three domains. Currently, no scale in Thai exists that measures 'caregiver contribution' to patients with heart failure or any long-term condition. 'Caregiver burden' has been measured, but this is not a comparable construct. As such, future studies should evaluate the concurrent validity of the Thai version of the CC-SCHFI with the Thai version of the SCHFI. The SCHFI might be used to determine criteria outcomes, i.e. whether caregiver intervention for the patient is reflected in the latter's ability to care for themself and, hence, a suitable score on the SCHFI.

There are some limitations to our study that should be noted. First, only caregiver, not patient, self-care data were obtained, so we are unable to determine impact of caregiver contributions to heart failure patient self-care. Second, data were collected on one occasion only, so we are unable to estimate scale item stability. Third, in the absence of a well-established comparable measure, we were unable to determine concurrent validity. Fourth, our sample size 


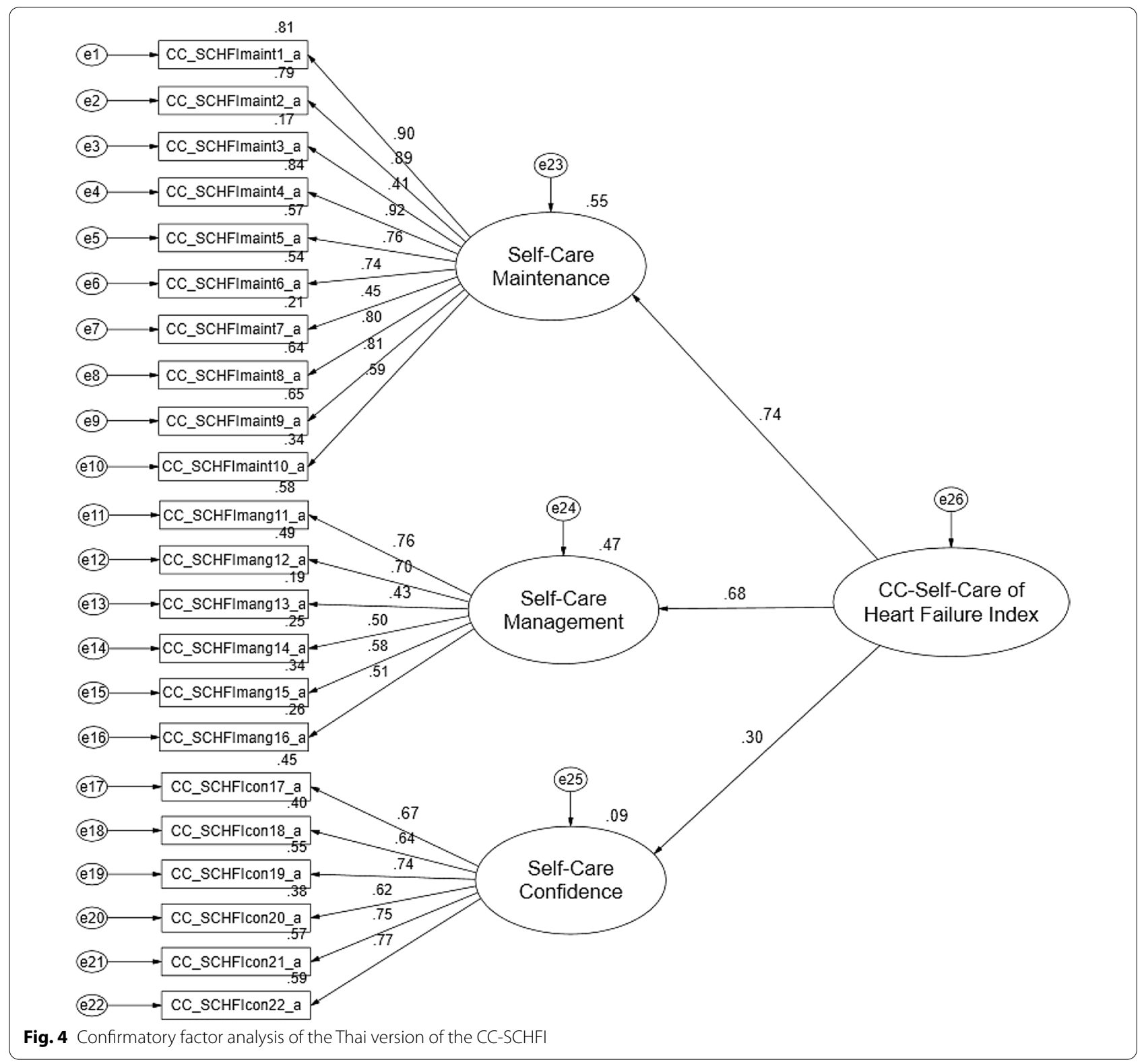

Table 3 Composite reliability, McDonald's omega and average variance extracted for each CC-SCHFI scale

\begin{tabular}{llll}
\hline CC-SCHFI scale & CR & $\begin{array}{l}\text { McDonald's } \\
\text { omega }\end{array}$ & AVE \\
\hline Self-care maintenance & 0.992 & 0.963 & 0.557 \\
Self-care management & 0.757 & 0.751 & 0.515 \\
Self-care confidence & 0.852 & 0.856 & 0.592 \\
\hline
\end{tabular}

CR Composite reliability, AVE Average variance extracted

may be deemed small, but as CFA recommendations for sample size-to-item ratio range vastly from 3-20 with absolute ranges with a minimum of 100 [42], we believe it to be acceptable. Moreover, it is comparable to the sample $(\mathrm{n}=99)$ reported in the study validating the CC-SCHFI in a South American population [26]. For SEM, again this varies, with rules of thumb of 10 cases/observations per indicator variable in setting a lower bound of an adequate sample size, though the ratio can be as low as 5 to 1 [43]. Finally, shortly after commencing this study, a revised version of the CC-SCHFI [22] was published, and a translation and psychometric evaluation of this is warranted.

\section{Conclusions}

The Thai version of the CC-SCHFI is a reliable and valid instrument to measure the contributions of caregivers to the self-care of patients with heart failure. This is the first 
Table 4 Fit indices for each scale of the Thai version of the CC-SCHFI

\begin{tabular}{lllllllllll}
\hline CC-SCHFI scale & Chi-square/df & Sig & CMIN/df & GFI & AGFI & NFI & IFI & CFI & RMR & RMSEA \\
\hline Maintenance & $18.409 / 15.0$ & 0.242 & 1.227 & 0.965 & 0.873 & 0.986 & 0.997 & 0.997 & 0.021 & 0.048 \\
Management & $2.416 / 3.0$ & 0.491 & 0.805 & 0.992 & 0.944 & 0.992 & 1.002 & 1.000 & 0.016 & 0.000 \\
Confidence & $13.580 / 9.0$ & 0.138 & 1.509 & 0.958 & 0.903 & 0.941 & 0.979 & 0.976 & 0.022 & 0.050
\end{tabular}

GFI Goodness of Fit Index, AGFI adjusted Goodness of Fit Index, NFI Normed Fit Index, IFI Incremental Fit Index, CFI Comparative Fit Index, RMR root mean square residual, RMSEA Root Mean Square Error of Approximation

instrument of its kind for use in a Thai population and appears to be useful for clinical and research purposes. Further studies to examine the use of this version of the instrument among other populations and settings are warranted.
For example, consideration may be given to using the actorinterdependence model to estimate different dyadic patterns.

\section{Appendix: Thai version of the CC-SDCHFI}

\section{การสงเสริมการดูแลตนเองของผู้ป่วยที่มีภาวะหัวใจล้มเหลวของผู้ดูแล}

\section{คำตอบทั้งหมดจะเก็บรักษาเป็นความลับ}

ข้าพเจ้าขอให้ท่านนึกการดูแลผู้ป่วยที่มีภาวะหัวใจลัมเหลวในระยะ 1 เดือนที่ผ่านมา

คำตอบของท่านไม่มีถูกหรือผิด

ท่านได้แนะนำบุคคลที่ท่านดูแลในสิงต่างๆ เหล่านี้บ่อยเพียงใด (หรือท่านทำสิ่งต่างๆ

เหล่านี้แทนเนื่องจากบุคคลที่ท่านดูแลไม่สามารถทำได้บ่อยเพียงใด)

ส่วนที่ 1:

\begin{tabular}{|c|c|c|c|c|}
\hline & $\begin{array}{l}\text { ไม่เคยเลย } \\
\text { หรือแทบจะไม่ } \\
\text { เคยเลย }\end{array}$ & บางครั้ง & บ่อยครั้ง & $\begin{array}{l}\text { เป็นประจำหรี } \\
\text { อทุกวัน }\end{array}$ \\
\hline 1. ให้ชั่งน้ำหนัก & 1 & 2 & 3 & 4 \\
\hline 2. ให้ตรวจดูอาการบวมบริเวณข้อเท้า & 1 & 2 & 3 & 4 \\
\hline $\begin{array}{l}\text { 3. ให้พยายามหลีกเลี่ยงการเจ็บป่วย เช่น โรคไข้หวัดใหญ่ } \\
\text { หลีกเลี่ยงการเข้าใกล้ผู้ป่วยคนอื่น }\end{array}$ & 1 & 2 & 3 & 4 \\
\hline 4. ให้มีกิจกรรมการออกแรงทางกาย & 1 & 2 & 3 & 4 \\
\hline 5. ให้ไปตรวจตามที่หมอ หรือ พยาบาลนัด & 1 & 2 & 3 & 4 \\
\hline 6. ให้รับประทานอาหารที่มีเกลือต่ำ & 1 & 2 & 3 & 4 \\
\hline 7. ให้ออกกำลังกายเป็นระยะเวลา 30 นาที & 1 & 2 & 3 & 4 \\
\hline 8. ไม่ลืมรับประทานยา & 1 & 2 & 3 & 4 \\
\hline $\begin{array}{l}\text { 9. ให้เลือกรับประทานอาหารที่มีเกลือต่ำเมื่อต้องออกไปรับ } \\
\text { ประทานอาหารนอกบ้าน หรือออกไปเยี่ยมเยียนผู้อื่น }\end{array}$ & 1 & 2 & 3 & 4 \\
\hline $\begin{array}{l}\text { 10. ให้ใช้ระบบเตือนความจำ (กล่องยา } \\
\text { เครื่องเตือนความจำ) } \\
\text { เพื่อชวยให้นึกถึงการรับประทานยา }\end{array}$ & 1 & 2 & 3 & 4 \\
\hline
\end{tabular}


ส่วนที่ 2:

ผู้ป่วยจะแสดงอาการเนื่องจากภาวะหัวใจลัมเหลว เช่นปัญหาการหายใจลำบาก และการบวมบริเวณข้อเท้าซึ่งเป็นอาการโดยทั่วไปของภาวะหัวใจล้มเหลว

ในระยะ 1 เดือนที่ผ่านมา บุคคลที่ท่านดูแลมีปัญหาเกี่ยวกับการหายใจลำบาก หรือมีอาการบวมบริเวณข้อเท้าหรือไม่ (ให้เลือกวงกลมเพียง 1 คำตอบ)

0) ไม่มี

1) มี

11. หากบุคคลที่ท่านดูแลมีปัญหาเกี่ยวกับการหายใจลำบาก หรือมีอาการบวมบริเวณข้อเท้าในระยะ 1 เดือนที่ผ่านมา (ให้เลือกวงกลมเพียง 1 คำตอบ)

\begin{tabular}{|lc|c|cccc}
\hline & ไม่เคยมี & ไม่รู้เลย & ไม่เร็ว & ค่อนข้างเร็ว & เร็ว & เร็วมาก \\
\hline $\begin{array}{l}\text { ท่านใช้เวลานานแค่ไหนกว่าจะรู้ว่าเป็นอาก } \\
\text { ารของภาวะหัวใจล้มเหลว }\end{array}$ & $\mathrm{N} / \mathrm{A}$ & 0 & 1 & 2 & 3 & 4 \\
\hline
\end{tabular}

หากบุคคลที่ท่านดูแลมีปัญหาเกี่ยวกับการหายใจลำบาก หรือมีอาการบวมบริเวณข้อเท้า ท่านได้แนะนำวิธีการรักษาเหล่านี้บ่อยเพียงใด (ให้เลือกวงกลมเพียง 1 คำตอบของแต่ละวิธีการรักษา)

\begin{tabular}{|lccccc|}
\hline & ไม่เคยเลย & บางครั้ง & บ่อย & สม่ำเสมอ \\
\hline 12.ให้ลดปริมาณเกลือในอาหาร & 1 & 2 & 3 & 4 \\
\hline 13.ให้ลดปริมาณการดื่มน้ำและของเหลว & 1 & 2 & 3 & 4 \\
\hline 14.ให้รับประทานยาขับปัสสาวะเพิ่มขึ้น & 1 & 2 & 3 & 4 \\
\hline 15.ให้ติดต่อพยาบาลหรือแพทย์เพื่อขอคำแนะนำ & 1 & 2 & 3 & 4 \\
\hline
\end{tabular}


16.ให้ท่านนึกถึงวิธีการรักษาที่ท่านใช้ครั้งล่าสุดกับผู้ป่วยในความดูแลของท่านเมื่อมีปัญหาเกี่ยวกับการหายใจลำบาก หรือมีอาการบวมบริเวณข้อเท้า (ให้เลือกวงกลมเพียง 1 คำตอบ)

\begin{tabular}{|l|c|cccc|}
\hline & $\begin{array}{c}\text { ฉันไม่ได้ทำอะไร } \\
\text { เลย }\end{array}$ & ไม่แน่ใจ & ค่อนข้างมั่นใจ & มั่นใจ & มั่นใจมาก \\
\hline $\begin{array}{l}\text { ท่านมันใจแค่ไหนว่าวิธีการรักษานั้นช่ยไไ } \\
\text { ด้หรือชวยไม่ได้ }\end{array}$ & 0 & 1 & 2 & 3 & 4 \\
\hline
\end{tabular}

ส่วนที่ 3:

โดยทั่วไปแล้วท่านมั่นใจแค่ไหนว่าท่านสามารถช่วยเหลือบุคคลที่ท่านดูแลได้

\begin{tabular}{|lcccc|}
\hline & ไม่มั่นใจ & ค่อนข้างมั่นใจ & มั่นใจมาก & มั่นใจที่สุด \\
\hline 17.ช่วยให้เขา/เธอไม่มีอาการของภาวะหัวใจลัมเหลว & 1 & 2 & 3 & 4 \\
\hline 18.ช่วยให้ผู้ป่วยปฏิบัติตามข้อแนะนำการรักษา & 1 & 2 & 3 & 4 \\
\hline 19.ประเมินการแสดงอาการที่สำคัญๆได้ & 1 & 2 & 3 & 4 \\
\hline $\begin{array}{l}\text { 20.รู้ทันการเปลี่ยนแปลงทางด้านสุขภาพที่ของเขา/เธอที่เ } \\
\text { กิดขึ้น }\end{array}$ & 1 & 2 & 3 & 4 \\
\hline 21.ปฏิบัติบางอย่างเพื่อชวยบรรเทาอาการของเขา/เธอ & 1 & 2 & 3 & 4 \\
\hline 22.ประเมินผลวิธีการรักษาว่าชวยได้หรือไม่ & 1 & 2 & 3 & 4 \\
\hline
\end{tabular}

\section{Abbreviations}

CC-SCHFI: Caregiver Contribution to Self-Care of Heart Failure Index (CCSCHFI); CFA: Confirmatory factor analysis; CFI: Comparative fit index; GFI: Goodness of fit index; AGFI: Adjusted goodness of fit index; IFI: Incremental fit index; NFI: Normed fit index; RMSEA: Root mean square error of approximation; RMSR: Root mean square residual.

\section{Acknowledgements}

The authors thank the caregivers for participating in the study, and Ercole Vellone for granting permission to use the CC-SCHFI.

\section{Authors' contributions}

NS, NW, DRT and CFS conceived and designed the study. NS and NW recruited participants, collected the data, conducted the analysis and drafted the paper. DRT and CFS contributed to data analysis and drafting the paper. All authors read and approved the final manuscript.

\section{Funding}

The authors declare that they have not received any funding in relation to this study.

\section{Availability of data and materials}

The datasets used and/or analyzed during the present study and the Thai version of the CC-SCHFI are available from the corresponding author on reasonable request.

\section{Declarations}

\section{Ethics approval and consent to participate}

All study procedures were in accordance with the ethical standards of the institutional review board (SRU 2019_308) and with the 1964 Helsinki declaration and its later amendments or comparable ethical standards. Informed consent was obtained from all individual participants before data collection.

\section{Consent for publication}

Not applicable.

\section{Competing interests}

The authors declare that they have no competing interests.

\section{Author details}

${ }^{1}$ Faculty of Nursing, Surat Thani Rajabhat University, Surat Thani, Thailand.

${ }^{2}$ School of Nursing and Midwifery, Medical Biology Centre, Queen's University Belfast, 97 Lisburn Road, Belfast BT9 7BL, UK. ${ }^{3}$ Integrated Care Academy,

University of Suffolk, Ipswich, UK.

Received: 13 April 2021 Accepted: 2 July 2021

Published online: 10 July 2021

\section{References}

1. Savarese G, Lund LH. Global public health burden of heart failure. Card Fail Rev. 2017;3(1):7-11. 
2. Laothavorn P, Hengrussamee K, Kanjanavanit R, Moleerergpoom W, Laorakpongse D, Pachirat O, et al. Thai Acute Decompensated Heart Failure Registry (Thai ADHERE). CVD Prev Control. 2010;5(3):89-95. https:// doi.org/10.1016/j.cvdpc.2010.06.001.

3. Lam CSP. Heart failure in Southeast Asia: facts and figures. ESC Heart Fail. 2015;2(2):46-9. https://doi.org/10.1002/ehf2.12036.

4. Moleerergpoom W, Hengrussamee K, Pyayotai D, et al. Predictors of inhospital mortality in acute decompensated heart failure (Thai ADHERE). J Med Assoc Thai. 2013:96(2):157-64.

5. Krittayaphong R, Laothavron P, Hengrussamee K, Sanguanwong S, Kunjara-Na-Ayudhya R, Rattanasumawong K, Komoltri C, Sritara P. Thai ADHERE Registry Group Ten-year survival and factors associated with increased mortality in patients admitted for acute decompensated heart failure in Thailand. Singapore Med J. 2020;61(6):320-6.

6. Tankumpuan T, Asano R, Koirala B, Dennison-Himmelfarb C, Sindhu S, Davidson PM. Heart failure and social determinants of health in Thailand: an integrative review. Heliyon. 2019;5(5): e01658. https://doi.org/10. 1016/j.heliyon.2019.e01658.

7. Srisuk N, Cameron J, Ski CF, Thompson DR. Randomized controlled trial of family-based education for patients with heart failure and their carers. J Adv Nurs. 2017;73(4):857-70. https://doi.org/10.1111/jan.13192.

8. Tamdee D, Tamdee P, Greiner C, Boonchiang W, Okamoto N, Isowa T. Conditions of caring for the elderly and family caregiver stress in Chiang Mai. Thailand J Health Res. 2019;33(2):138-50. https://doi.org/10.1108/ JHR-07-2018-0053.

9. Wongpun S, Guha S. Caregivers for the elderly in Thailand: development and evaluation of an online support system. Inform Develop. 2020;36(1):112-27. https://doi.org/10.1177/0266666918821715.

10. Kruk ME, Gage AD, Arsenault C, Jordan K, Leslie HH, Roder-DeWan S, et al. High-quality health systems in the Sustainable Development Goals era: time for a revolution. Lancet Global Health Commission. 2018;6(11):e1 196-252. https://doi.org/10.1016/S2214-109X(18)30386-3.

11. Phrommintikul A, Buakhamsri A, Janwanishstaporn S, Sanguanwong S, Suvachittanont N. Heart failure guideline: acute heart failure. J Med Assoc Thai. 2019:102(3):373-9.

12. Toback M, Clark N. Strategies to improve self-management in heart failure patients. Contemp Nurse. 2017;53(1):105-20. https://doi.org/10.1080/ 10376178.2017.1290537.

13. Jaarsma T, Stömberg A, Ben Gal T, Cameron J, Driscoll A, Duengen HD, et al. Comparison of self-care behaviors of heart failure patients in 15 countries worldwide. Patient Educ Couns. 2013;92(1):114-20. https://doi. org/10.1016/j.pec.2013.02.017

14. Riegel B, Driscoll A, Suwanno J, Moser DK, Lennie TA, Chung ML, et al. Heart failure self-care in developed and developing countires. J Card Fail. 2009;15(6):508-16. https://doi.org/10.1016/j.cardfail.2009.01.009.

15. Srisuk N, Cameron J, Ski CF, Thompson DR. Heart failure family-based education: a systematic review. Patient Educ Counsel. 2016;99(3):326-38. https://doi.org/10.1016/j.pec.2015.10.009.

16. Bidwell JT, Lyons KS, Lee CS. Caregiver well-being and patient outcomes in heart failure: a meta-analysis. J Cardiovasc Nurs. 2017;32(4):372-82. https://doi.org/10.1097/JCN.00000000000000350.

17. Kitko L, Mcllvennan CK, Bidwell JT, Dionne-Odom JN, Dunlay SM, Lewis LM, et al. Family caregiving for individuals with heart failure: a scientific statement from the American Heart Association. Circulation. 2020;141(22):e864-78. https://doi.org/10.1161/CIR.0000000000000768.

18. Harkness K, Buck HG, Arthur H, Carroll S, Cosman T, McGillion M, et al. Caregiver contribution to heart failure self-care (CACHS). Nurs Open. 2016;3(1):51-60. https://doi.org/10.1002/nop2.35.

19. Strömberg A, Bonner N, Grant L, Bennett B, Chung M, Jaarsma T, et al. Psychometric validation of the Heart Failure Caregiver Questionnaire (HFCQ). Patient. 2017;10(5):579. https://doi.org/10.1007/s40271-017-0228-x.

20. Humphrey L, Kulich K, Deschaseaux C, Blackburn S, Maguire L, Strömberg A. Caregiver Burden Questionnaire for Heart Failure (CBQ-HF): face and content validity. Health Qual Life Outcomes. 2013;11:84. https://doi.org/ 10.1186/1477-7525-11-84

21. Vellone E, Riegel B, Cocchieri A, Barbaranelli C, D'Agostino F, Glaser D, et al. Validity and reliability of the Caregiver Contribution to Self-Care of Heart Failure Index. J Cardiovasc Nurs. 2013;28(3):245-55. https://doi.org/10. 1097/JCN.0b013e318256385e

22. Vellone E, Barbaranelli C, Pucciarelli G, Zeffiro V, Alvaro R, Riegel B. Validity and reliability of the Caregiver Contribution to Self-Care of Heart Failure
Index version 2. J Cardiovasc Nurs. 2020;35(3):280-90. https://doi.org/10. 1097/JCN.0000000000000655.

23. Riegel B, Barbaranelli C, Carlson B, Sethares KA, Daus M, Moser DK, et al. Psychometric testing of the revised Self-Care of Heart Failure Index. J Cardiovasc Nurs. 2019;34(2):183-92. https://doi.org/10.1097/JCN.00000 00000000543.

24. Suwanno J, Petpichetchian W, Riegel B, Issaramalai SA. A model predicting health status of patients with heart failure. J Cardiovasc Nurs. 2009;24(2):118-26. https://doi.org/10.1097/JCN.0b013e318197a75.

25. World Health Organization. Process of translation and adaptation of instruments. Visited 12.3.20. Available at: https://www.coursehero.com/ file/30372721/WHO-Process-of-translation-and-adaptation-of-instrument spdf/

26. Ávila CW, De Maria M, Vellone E, Riegel B, Bernardes D, Silveira L, et al. Psychometric characteristics of the Caregiver Contribution to Self-Care of Heart Failure Index in a South American population. J Cardiovasc Nurs. 2020;35(4):435-44. https://doi.org/10.1097/JCN.00000000000000707.

27. Terwee CB, Bot SDM, de Boer MR, van der Windt DAWM, Knol DL, Dekker J, et al. Quality criteria were proposed for measurement properties of health status questionnaires. J Clin Epidemiol. 2007;60(1):34-42. https:// doi.org/10.1016/j.jclinepi.2006.03.012.

28. Terwee CB, Mokkink LB, Knol DL, Ostelo RWJG, Bouter LM, de Vet HCW. Rating the methodological quality in systematic reviews of studies on measurement properties: a scoring system for the COSMIN checklist. Qual Life Res. 2012;21(4):651-7. https://doi.org/10.1007/s11136-011-9960-1.

29. $\mathrm{Li} \mathrm{CH}$. Confirmatory factor analysis with ordinal data: comparing robust maximum likelihood and diagonally weighted least squares. Behav Res Methods. 2016;48(3):936-49. https://doi.org/10.3758/s13428-015-0619-7.

30. Bland JM, Altman DG. Cronbach's alpha. BMJ. 1997;314:572. https://doi. org/10.1136/bmj.314.7080.572.

31. Beland S, Cousineau D, Loye N. Using the Mcdonald's omega coefficient instead of Cronbach's alpha. McGill J Educ. 2017;52(3):791-804. https:// doi.org/10.7202/1050915ar.

32. Gignac GE, Reynolds MR, Kovacs K. Digit Span subscale scores may be insufficiently reliable for clinical interpretation: distinguishing between stratified coefficient alpha and omega hierarchical. Assessment. 2019;26(8):1554-63. https://doi.org/10.1177/1073191117748396.

33. Hu L, Bentler PM. Fit indices in covariance structure modeling: sensitivity to underparameterized model misspecification. Psychol Methods. 1998;3(4):424-53. https://doi.org/10.1037/1082-989X.3.4.424.

34. Bollen KA. Structural equations with latent variables. New York: John Wiley; 1989.

35. Jöreskog KG, Sörbon D. LISREL 8: user's reference guide. Lincolnwood, IL: Scientific Software International; 1996.

36. Hair JFJ, Anderson RE, Tatham RL, Black WC. Multivariate data analysis. $6^{\text {th }}$ edn. Upper Saddle River, NJ, Prentice Hall; 2006.

37. Hu L, Bentler PM. Cutoff criteria for fit indexes in covariance structure analysis: conventional criteria versus new alternatives. Struct Equ Modeling. 1989;6(1):1-55. https://doi.org/10.1080/10705519909540118.

38. Barrett P. Structual equation modelling: adjudging model fit. Pers Individ Diff. 2007;42(5):815-24. https://doi.org/10.1016/j.paid.2006.09.018.

39. Bentler PM, Bonett DG. Significance tests and goodness of fit in the analysis of covariance structures. Psychol Bull. 1980;88(3):588-606. https://doi. org/10.1037/0033-2909.88.3.588.

40. Fornell C, Larcker DF. Evaluating structural equation models with unobservable variables and measurement error. J Market Res. 1981;18(1):3950. https://doi.org/10.2307/3151312.

41. Teo TS, Srivastava SC, Jiang L. Trust and electronic government success: an empirical study. Manag Inf Syst. 2009;25(3):99-132. https://doi.org/10. 2753/MIS0742-1222250303.

42. Mundfrom DJ, Shaw DG, Ke TL. Minimum sample size recommendations for conducting factor analyses. Int J Testing. 2005;5(2):159-68. https://doi. org/10.1207/s15327574ijt0502_4.

43. Kline RB. Principles and practice of structural equation modeling. 2nd edn. New York, NY: Guilford; 2015.

\section{Publisher's Note}

Springer Nature remains neutral with regard to jurisdictional claims in published maps and institutional affiliations. 